\title{
Mixed messages: Racial science and local identity in Bali and Lombok, 1938-39
}

\author{
Fenneke Sysling
}

\begin{abstract}
This article explores how the islands of Bali and Lombok were racialised through the work of Dutch racial scientist J.P. Kleiweg de Zwaan in the 1930s. An examination of both Kleiweg's published works and his local practices draws attention to the fact that racialisation occurred at different moments of anthropological work, producing different outcomes. The article concludes that anthropologists communicated different versions of racial ideas to international academics and to local communities. The Bali-Aga and Sasak, who were measured, described and photographed by anthropologists, appropriated racial categories which they found meaningful.
\end{abstract}

Bali in the 1930s was a popular fieldwork site for anthropologists. It is best known for the visits of American cultural anthropologists such as Margaret Mead and Gregory Bateson, but the work of Dutch colonial ethnographers on the island is also well documented. This article focuses on a different type of anthropologist: the physical anthropologist or racial scientist, whose interest was in the body rather than in cultural interactions, and in race rather than personality. The protagonist of this study, J.P. Kleiweg de Zwaan, was a Dutch physical anthropologist who specialised in the Indonesian archipelago and who visited Bali and Lombok in 1938-39. He had been in the Indies twice before as a young man; by the time he returned in the late 1930s he was in his sixties and a well-known professor of anthropology, based at the Colonial Institute in Amsterdam. Through his work, he racialised difference in Bali and Lombok.

Physical anthropology first appeared in the Netherlands Indies in the second half of the nineteenth century, and was able to thrive on the opportunities provided by the Empire well into the twentieth century. From the start, racial science was the subject of criticism. Margaret Mead was one of its American critics, exposing the flaws of racial research and racial thought. ${ }^{1}$ Her work increasingly focused on culture and personality (and how the former influenced the latter) and on observation and visual

Fenneke Sysling is a Postdoctoral Researcher at the University of Utrecht. Correspondence in connection with this article may be addressed to: f.h.sysling@uu.nl.

I would like to thank the Netherlands Organisation for Scientific Research (NWO) which financed the project 'Sites, Bodies, Stories', programme number 312-52-103, which led to this article.

1 Margaret Mead, 'The methodology of racial testing: Its significance for sociology', American Journal of Sociology 31, 5 (1926): 465-8. 
anthropology. Bali, where Mead stayed with her then husband and fellow anthropologist Gregory Bateson, was one of the field sites where they practised this new direction. ${ }^{2}$ But while it is easy to present Bateson and Mead as innovators who opened up new spaces of research on Bali in the late 1930s and Kleiweg's research as the swan song of the old racial anthropology, in fact Dutch racial science had one of its most productive decades in the Netherlands Indies in the 1930s. Physical anthropology was practised by military doctors stationed all over the Indies, by professional anthropologists who arrived from the Netherlands to do fieldwork for a few months, and by the anatomists in the medical schools at Batavia (today's Jakarta) and Surabaya. ${ }^{3}$

In the nineteenth century physical anthropology - the study of biological differences and similarities between large groups of people (or 'races') and their origin and evolution - had crystallised into a modern discipline that was built on the idea that a quantitative approach would make the study of races more objective. While skulls and skeletons had always been important to the discipline, anthropometry - the measuring of living bodies - became more important in the late nineteenth century when some anthropologists became disappointed with their collections of skulls, and fieldwork became more feasible. With the help of instruments such as measuring tapes and eye colour charts, physical anthropologists conducted fieldwork and measured thousands of people throughout the world, seeking to amass anthropometric data that could be used to compare, categorise, and evaluate races more 'objectively' than before. ${ }^{4}$ In the Netherlands, physical anthropologists were influenced by French and German advances in anthropology and realised the research potential of their Eastern colonies. Dutch colonial doctors had started taking racial measurements from the 1860s, but with the new phase of imperialism around 1900 that included the opening up of the 'Outer' Islands of the archipelago, an increasing number of Indigenous Indonesians were confronted by anthropologists from the Netherlands on expeditions to measure people in their 'natural habitat'.

For racial scientists, Bali and Lombok were not only at the crossroads of the eastern and western parts of the archipelago, but also a place of intersection of Hindu and pre-Hindu characteristics, higher and lower castes, mountains and lowlands, and Batak and Malay races. The two islands were conceptualised as an internally

2 Ira Jacknis, 'Margaret Mead and Gregory Bateson in Bali: Their use of photography and film', Cultural Anthropology 3, 2 (1988): 160-77.

3 Fenneke Sysling, Racial science and human diversity in colonial Indonesia (Singapore: NUS Press, 2015), pp. 16-22.

4 See George W. Stocking, ed., Bones, bodies, behavior: Essays on biological anthropology (Madison: University of Wisconson Press, 1988); G.W. Stocking, Victorian anthropology (London: Collier MacMillan, 1987). See also Lorraine Daston and Peter Galison, Objectivity (Cambridge, MA: Zone, 2007); Susan Lindee and Ricardo Ventura Santos, 'The biological anthropology of living human populations: World histories, national styles, and international networks', Current Anthropology 53, S5 (2012): 5; Gert Theile, Anthropometrie: Zur Vorgeschichte des Menschen nach Maß (München: Fink, 2005).

5 For a bibliography of racial science of the Dutch Indies until 1923, see Johannes Pieter Kleiweg de Zwaan, Physical anthropology in the Indian Archipelago and adjacent regions (Amsterdam: Royal Academy of Science, 1923). For the new Dutch imperialism see Maarten Kuitenbrouwer, The Netherlands and the rise of modern imperialism: Colonies and foreign policy, 1870-1902 (New York: Berg, 1991); Elsbeth Locher-Scholten, 'Dutch expansion in the Indonesian Archipelago around 1900 and the imperialism debate', Journal of Southeast Asian Studies 25, 1 (1994): 91-111. 
heterogeneous unit that should be analysed according to its internal differences, and then compared with its neighbouring islands and peoples - particularly with Java to the west and the other Lesser Sunda Islands to the east. The ultimate aim of anthropologists would be to understand the different 'layers' of the population and to place them on a scale of originality, to draw boundaries, and to understand Bali and Lombok within the racial make-up of the entire archipelago. Kleiweg de Zwaan too, was most interested in the 'original people' of Bali and Lombok and wanted to study the difference between the supposedly more original Bali-Aga and the other Balinese, and between the Balinese and the Sasak of east Lombok. Because of their supposedly pure state, the Bali-Aga, in the words of Frie Kleiweg de Zwaan-Vellema, Kleiweg's wife and research assistant, were 'an exquisite restaurant for anthropologists and ethnologists' ${ }^{6}$

This article argues that racialisation, the 'extension of racial meaning to a previously racially unclassified relationship', as Michael Omi and Howard Winant have defined it, is not a straightforward process. ${ }^{7}$ In the case of racial science on Bali and Lombok racialisation took place at different moments, during fieldwork and afterwards in published work, each with different outcomes. This article aims to reveal how anthropologists communicated ideas about race to distinct audiences, both in the field and back home - not only to an academic audience but also to local and Indigenous communities during fieldwork. Andrew Zimmerman has argued that racial fieldwork in Germany trained Germans to perceive racial differences as significant. ${ }^{8}$ I suggest that in the case of Bali and Lombok, physical anthropologists aimed to place the islands within a wider framework of racial influences, based on anthropological and colonial categories, while local Balinese and Sasak appropriated only those racial categories they found meaningful, and used them on their own terms.

In order to show how ideas about racial difference were made and how they were challenged, this article first lays out the position of Bali and Lombok in anthropological discussions about the archipelago because these discussions formed the background to Kleiweg de Zwaan's research. It then looks at Kleiweg's fieldwork and the part played by the Balinese and the Sasak during their anthropometric encounters. Finally, I analyse Kleiweg's published work, in which he argued that his anthropological photographs were more significant than previously published anthropometric measurements for determining race in Bali and Lombok.

\section{De Zwaan and Dutch racial science}

Based at the Colonial Institute in Amsterdam, Johannes Pieter Kleiweg de Zwaan was a key figure in the racial science of the Dutch Empire and his lifespan coincided with the heyday of the discipline. In 1903, when he graduated from medical school, physical anthropologists had added fieldwork among living people to their research at the anatomical museum. Kleiweg retired officially in 1939, but his anthropological

6 Kleiweg de Zwaan family papers, notes by Mrs. Kleiweg de Zwaan-Vellema, n.d., but after the Second World War, p. 3.

7 Michael Omi and Howard Winant, Racial formation in the United States: From the 1960s to the 1990s (London: Routledge, 1986), p. 64.

8 Andrew Zimmerman, Anthropology and antihumanism in imperial Germany (Chicago: University of Chicago Press, 2001), ch. 6. 
output continued until long after the Second World War, and he lived to see both Indonesia's declaration of independence (1945) and the transfer of sovereignty from the Netherlands to Indonesia of West New Guinea (1962), along with the end of Dutch physical anthropological activities. Thanks partly to Kleiweg's colonial expertise, the collections that he had amassed there, and his skills in building and activating a network of physical anthropologists, Amsterdam became, for a short period, the centre for racial knowledge of Southeast Asia.

Kleiweg was influenced mostly by the liberal generation of German physical anthropologists, and before he travelled to the Indies for the first time he took an intensive course in Berlin with Felix von Luschan, who held the second chair in physical anthropology in Germany. Luschan and other scholars such as the Swiss Rudolf Martin, whose methods Kleiweg later followed, are seen by historians as part of the liberal anthropology of the late nineteenth century, which was succeeded by a more blatantly racist generation of anthropologists. ${ }^{9}$ Like Martin, Kleiweg refrained from connecting biological characteristics to 'primitive mentality'. This did not mean that he did not hold any prejudices in regard to the Indigenous people of the East, or that he did not work to place peoples on an evolutionary ladder from primitive and primeval to modern and civilised. It does mean, however, that he emphasised the collection of raw data over sweeping assertions and that he did not link brain size or posture to intelligence or to the capacity to be civilised.

Indeed, Kleiweg's visit to Bali in 1938 should be considered in the light of his growing unease with developments in Germany. In 1935 he had written a page-long essay in a pamphlet denouncing racial research in Germany. There Kleiweg argued that it was not yet proven in any way that races had different mental and moral characteristics. He also raised objections to the idea that Aryans and Jews could be defined anthropologically as pure races. ${ }^{10}$ While he had written earlier that anthropology as a discipline included psychological characteristics, Kleiweg quietly abandoned this notion in the 1930s. In his 1943 booklet on the 'aim and development' of anthropology he merely stated that 'there are anthropologists and schools that want to incorporate the mental and cultural qualities of people and races in this study [of anthropology]. In my opinion this is undesirable and it is better to leave the study of those features to the psychologist and ethnologist'. ${ }^{11}$ He never, however, questioned the pre-eminence of race as the central ordering principle of physical anthropology.

9 Robert Proctor, 'From anthropology to rassenkunde in the German anthropological tradition', in Stocking, Bones, bodies, behavior, pp. 138-79; Benoit Massin, 'From Virchow to Fischer: Physical anthropology and "modern race theories" in Wilhelmine Germany', in Volksgeist as method and ethic: Essays on Boasian ethnography and the German anthropological tradition, ed. George W. Stocking (Madison: University of Wisconsin Press, 1996), pp. 79-155; Andrew D. Evans, Anthropology at war: World War I and the science of race in Germany (Chicago: University of Chicago Press, 2010), pp. 5-7; H. Glenn Penny and Matti Bunzl, 'Introduction', in Worldly provincialism: German anthropology in the age of empire, ed. H.G. Penny and M. Bunzl (Ann Arbor: University of Michigan Press, 2003), p. 7. 10 Johannes Pieter Kleiweg de Zwaan, 'Onrecht aan de Joden', in Stemmen van Nederlanders over de behandeling der Joden in Duitschland, ed. A. Asscher and D. Cohen with Comité voor Bijzondere Joodsche Belangen (Amsterdam: Joachimsthal, 1935), p. 13.

11 Johannes P. Kleiweg de Zwaan, Doelstelling en ontwikkeling der anthropologie (The Hague: Servire, 1943), pp. 10-11. 
Kleiweg had started his career in the 1910s with two stints of fieldwork in the west of the archipelago, in central Sumatra and on the island of Nias, but had worked from the Netherlands in the following decades. At the end of the 1930s he was eager to go back to the Indies for a third time. When his request for funding from the university was denied, he tendered his resignation and went anyway, travelling with his wife and daughter. Two decades earlier he had written that he would have liked to visit a 'natural people', who seemed 'so much more interesting than a little developed cultural people, like the Malays from central Sumatra'. Bali and Lombok, however, were not considered very remote, nor seen as places where the most 'natural people' could be found. Bali had become a popular tourist destination and it is likely that Kleiweg chose Bali and Lombok because they were relatively quiet and easy to travel to with his family. ${ }^{12}$ Kleiweg had been there for a short trip after his fieldwork in 1907. 'It must be a beautiful country', he wrote to his father while he was reading Julius Jacobs' 1883 travel diary about Bali on his way there. ${ }^{13}$

\section{Bali and Lombok: At the crossroads of racial influences}

In the 1930s Bali became increasingly 'ethnologised' and was, in the words of Thomas A. Reuter, a 'test case for new methods of research and theoretical approaches' in anthropology. ${ }^{14}$ This was also true for physical anthropology. Although travellers had observed and written about the skin colour, posture, and hair type of the people of Bali and Lombok since the 1850s, actual physical anthropological research on the island had been scant, and started in the 1930s. ${ }^{15}$ By then, a particular representation of the Balinese had been established by ethnologists, administrators and tourists. From early representations of Bali as a place of danger and savagery, in the nineteenth century the island had been constructed as a place of ancient Hindu culture, a window to the archipelago's pre-Muslim past. Partly as a result of this idealisation, Bali's Hindu caste system became more rigid under the Dutch colonial administration from 1906-08 onward. Tourists arriving from the 1920s furthered the romantic image of the island, of sensual women, authentic artists, and exoticism. ${ }^{16}$

Lombok on the other hand was seen as an Islamic region. It was inhabited by a Sasak majority and a Balinese minority that had settled on the western part of the island. The Sasak of east Lombok had been supported by the Dutch when they rebelled against the Balinese in 1894 and subsequently Lombok became part of the Dutch Empire. The Sasak were seen as the original inhabitants of the island; for

12 Kleiweg de Zwaan family papers, letter from Kleiweg to his father, 27 Nov. 1907.

13 Kleiweg de Zwaan family papers, letter from Kleiweg to his father, 20 Aug. 1907; Adrian Vickers, Bali: A paradise created (Berkeley, CA: Periplus, 1989), p. 86.

14 Thomas A. Reuter, Custodians of the sacred mountains: Culture and society in the highlands of Bali (Honolulu: University of Hawai'i Press, 2002), p. 1.

15 Jan Willem Reiner Koch, Bijdrage tot de anthropologie der bewoners van Zuidwest Nieuw-Guinea; benevens uitkomsten van lichaamsmetingen verricht bij Javanen, Sumatranen, Baliërs en Sasaks (Leiden: Brill, 1908); Gerhard Heberer and Wolfgang Lehmann, Die Inland-Malaien von Lombok und Sumbawa: Anthropologische Ergebnisse der Sundaexpedition Rensch (Göttingen: Musterschmidt, 1950), based on research in the 1930s.

16 Vickers, Bali; Henk Schulte Nordholt, 'The making of traditional Bali: Colonial ethnography and bureaucratic reproduction', History and Anthropology 8, 1-4 (1994): 89-127. 
the Dutch, the Balinese and the Sasak nobility alike, Islam became a marker that distinguished the majority of Lombok's people from their Balinese neighbours. ${ }^{17}$

Bali and Lombok were not only conceptualised in religious or exotic terms but also racially. For physical anthropologists a single 'racial' other was less important than the different 'layers' of population, and Bali and Lombok were seen as regions in which various past migrations had left their mark. As historians of racial science have shown, islands were important field sites for physical anthropologists. It is remarkable, however, how different islands produced different narratives. Some islands, such as the Andamans, symbolised stagnation and degeneration, while other islands, such as Hawaii, signalled hybridity. Warwick Anderson has shown how Hawaiian diversity helped challenge scientific racism, and aided a new generation of anthropologists to formulate a critique of the older physical anthropology. ${ }^{18}$ In Southeast Asia, physical anthropologists emphasised the great diversity of the region. Bali and Lombok were particularly interesting to them because they had a population which combined many of the 'racial influences' spread through the rest of the archipelago. Bali also harboured the Indigenous Bali-Aga in whom Kleiweg de Zwaan was most interested. He hoped that his study of the physical differences between the Bali-Aga and the Balinese and between the Balinese and the Sasak of east Lombok would reveal the sources of the different racial 'elements' of the population, including its oldest elements in the Bali-Aga. ${ }^{19}$

Discussions among historians about the role of race in the Indies have so far focused mostly on the dichotomy between the rulers and the ruled. Scholars such as Ann Stoler and Frances Gouda emphasise how racial differences were made more rigid and how in the late nineteenth and twentieth century race-mixing was increasingly seen as a problem, while other scholars stress that these divisions were ambiguous and flexible, including not only notions of skin colour and other racial features, but also, and perhaps more importantly, notions of geography, civilisation, religion, language and morality. ${ }^{20}$ Although physical anthropologists were influenced by

17 Adrian Vickers, 'Hinduism and Islam in Indonesia: Bali and the Pasisir world', Indonesia 44 (1987): 31-58; Kari Telle, 'Changing spiritual landscapes and religious politics on Lombok', in Between harmony and discrimination: Negotiating religious identities within majority-minority relationships in Bali and Lombok, ed. Brigitta Hauser-Schäublin and David D. Harnish (Leiden: Brill, 2014), pp. 35-60.

18 Satadru Sen, 'Lost between Africa and Tasmania: Racializing the Andamanese', Journal of Colonialism and Colonial History 10, 3 (2009); Warwick Anderson, 'Racial hybridity, physical anthropology, and human biology in the colonial laboratories of the United States', Current Anthropology 53, S5, (2012): S95-S107. See also Ricardo Roque, 'Mountains and black races: Anthropology's heterotopias in colonial East Timor', Journal of Pacific History 47, 3 (2012): 263-82; Warwick Anderson and Hans Pols, 'The Mestizos of Kisar: An insular racial laboratory in the Malay Archipelago', this issue.

19 Johannes P. Kleiweg de Zwaan, Anthropologische Untersuchungen auf Bali und Lombok (Leiden: Brill, 1942), p. 24.

20 Ann Laura Stoler, Race and the education of desire: Foucault's history of sexuality and the colonial order of things (Durham: Duke University Press, 1995); A.L. Stoler, Carnal knowledge and imperial power: Race and the intimate in colonial rule (Berkeley: University of California Press, 2002); A.L. Stoler, Along the archival grain: Epistemic anxieties and colonial common sense (Princeton: Princeton University Press, 2009); Jean Gelman Taylor, The social world of Batavia: European and Eurasian in Dutch Asia (Madison: University of Wisconsin Press, 1983); Julia Clancy-Smith and Francis Gouda, ed., Domesticating the empire: Race, gender and family life in French and Dutch colonialism (Charlottesville: University Press of Virginia, 1998); Elsbeth Locher-Scholten, Women and the colonial state: Essays on gender and modernity in the Netherlands Indies, 1900-1942 (Amsterdam: Amsterdam 
what Gouda calls their 'white-skinned physicality', which defined what they perceived as different, they did emphasise internal diversity, and were interested in diversity and migration, something to which historians have paid too little attention. ${ }^{21}$ This is not to say that colonial society was not deeply divided, but that the idea of one 'native Indonesian race' was not conceptualised. ${ }^{22}$

This colonial discourse of racial (but also ethnic, religious and linguistic) pluralism was a common trope in writing about the Indies. These categorisations were everywhere; they represented what Stoler calls 'racialized common sense', '[t]hose sharp divisions between ethnic groups so familiar in descriptions of late-colonial Indonesia - where Batak was pitted against Javanese, Gayo against Malay, Chinese against Javanese'. ${ }^{23}$ This 'racialized common sense' may be described as a diffuse and tacitly shared form of colonial knowledge about differences between local people. This knowledge was created through centuries of interaction between Westerners and the inhabitants of the archipelago. It articulated local ideas of difference, histories of affinity and enmity between different ethnic groups, and other local and colonial prejudices. In this context, the idea of a diverse archipelago was also favoured by Dutch colonial discourse: as Robert Cribb notes, 'the cultural diversity of the archipelago meant that only the Dutch could rule impartially and fairly'. ${ }^{24}$

This 'racialized common sense' stimulated anthropological research and categorisation. Since the nineteenth century, racial discussions about the Balinese and the Sasak of Lombok had revolved around five axes of difference: Balinese versus Javanese; Malay versus proto-Malay or 'Indonesian'; Malay versus Papuan; Indian influence; and Bali-Aga versus later migrants. In the mode of racial scientists,

University Press, 2000); Frances Gouda, Dutch culture overseas: Colonial practice in the Dutch East Indies, 1900-1942 (Amsterdam: Amsterdam University Press, 1995); Ulbe Bosma and Remco Raben, Being "Dutch" in the Indies: A history of creolisation and empire, 1500-1920 (Singapore: NUS Press, 2008). See also Bart Luttikhuis, "Beyond race: Constructions of "Europeanness" in late-colonial legal practice in the Dutch East Indies', European Review of History 20, 4 (2013): 539-58; Susie Protschky, 'Race, class, and gender: Debates over the character of social hierarchies the Netherlands Indies, circa 16001942', Bijdragen tot de Taal-, Land- en Volkenkunde 167, 4 (2011): 543-56; Frances Gouda, Remco Raben, Henk Schulte Nordholt and Ann L. Stoler, 'Debate on Ann Laura Stoler, Along the archival grain: Epistemic anxieties and colonial common sense', Bijdragen tot de Taal-, Land-en Volkenkunde 165, 4 (2009): 551-67.

21 See for example, J.C. van Eerde, ed., De volken van Nederlandsch Indië in monographieën (Amsterdam: Elsevier, 1920-21); Frances Gouda, 'Colonial encounters, body politics, and flows of desire', Journal of Women's History 20, 3 (2008): 175.

22 For legal categories see Cees Fasseur, 'Cornerstone and stumbling block: Racial classification and the late colonial state in Indonesia', in The late colonial state in Indonesia: Political and economic foundations of the Netherlands Indies, 1880-1942, ed. Robert Cribb (Leiden: KITLV Press, 1994), pp. 38-9. This means that Elson's argument that a sense of racial unity of Indonesians developed among early nationalists has no precedent, nor is it very convincing that race played a greater role among these nationalists than the idea of modern citizenship. See Robert E. Elson, 'Constructing the nation: Ethnicity, race, modernity and citizenship in early Indonesian thought', Asian Ethnicity 6, 3 (2005): 152-4.

23 Stoler, Along the archival grain, p. 197.

24 Robert Cribb, 'Orang pendek and Papuans in colonial Indonesia', in A sea for encounters: Essays towards a postcolonial Commonwealth, ed. Stella Borg Barthet (Amsterdam: Rodopi, 2009), pp. 22342; R. Cribb, 'Pluralism and Dutch colonial policy in Indonesia', paper presented at the Twenty-first International Congress of Historical Sciences, Amsterdam, Aug. 2010. See also Elson, 'Constructing the nation', p. 156; Sysling, Racial science and human diversity, p. 16. 
Kleiweg set out to find whether body measurements could numerically demonstrate these preconceived categorisations. ${ }^{25}$

First, the Balinese were always compared to their Javanese neighbours. Wolter Robert van Hoëvell, a Dutch Protestant minister, scholar and later politician who travelled to Java, Madura and Bali in 1847, found the Balinese of slender build and taller than the Javanese, with a lighter skin. He also described them as having 'nobler and more symmetrical features' than the Javanese. ${ }^{26}$ These characteristics were often repeated by later authors. According to others, however, there was no difference in height. Pieter Lodewijk van Bloemen Waanders, for example, who had worked on Bali as an assistant resident (a colonial officer) in the late nineteenth century, did not see any difference between the Javanese and Balinese. ${ }^{27}$ Lombok was often seen as Bali's smaller sibling, different in religion but similar in race. This was the impression of the Irish linguist and ethnologist August Henry Keane, among other ethnologists of the period. ${ }^{28}$

Second, the Balinese and Sasaks were placed in discussions about the differences between Malays proper and earlier immigrants, the so-called 'proto-Malays', 'pre-Malays' or 'Indonesians'. The Batak of Sumatra were usually cited as the prime example of pre-Malays. In the late 1840s, German doctor, botanist and explorer Franz Junghuhn had put forward the notion that Sumatra was the 'original seat' of two different races - the Malays and the Batak. He grouped the Batak with the Dayak and Balinese. ${ }^{29}$ Medical doctor Julius Jacobs agreed with this categorisation of the Balinese based on his observations of women when he was in Bali administering smallpox vaccinations in the 1880s. Jacobs used his medical background to legitimise his gaze, arguing that Balinese women had breasts that were very different in shape from those of Javanese women. According to Adrian Vickers, Jacobs was the man who 'discovered the Balinese breast', and this emphasis would be repeated in many other publications. ${ }^{30}$ Jacobs' 'anatomical observations' did not only concern the breast, however. The broad shoulders and hips and large feet of Balinese women also suggested racial similarities with Batak women, rather than with the Javanese and other Malay women. 'Too bad that we did not bring Baudeloque's or

25 For other racial scientists and their categorisations in the region see: Bronwen Douglas and Chris Ballard, eds., Foreign bodies: Oceania and the science of race 1750-1940 (Canberra: ANU ePress, 2008); Hilary S. Howes, The race question in Oceania: A.B. Meyer and Otto Finsch between metropolitan theory and field experience, 1865-1914 (Frankfurt am Main: Peter Lang, 2013); Sandra Khor Manickam, Taming the wild: Aborigines and racial knowledge in colonial Malaya (Singapore: NUS Press, 2015).

26 Wolter R. van Hoëvell, Reis over Java, Madura en Bali, in het midden van 1847, pt 3 (Amsterdam: Van Kampen, 1854), p. 22.

27 Pieter Lodewijk van Bloemen Waanders, 'Bijdrage tot de kennis van het eiland Bali', Tijdschrift voor Nederlandsch Indië 3, 2 (1868): 375.

28 August Henry Keane, Eastern geography: A geography of the Malay Peninsula, Indo-China, the Eastern Archipelago, the Philippines and New Guinea (London: E. Stanford, 1892). See also Philipus P. Roorda van Eijsinga, Aardrijksbeschrijving van Nederlandsch Indië, ook ten dienste van hen, die zich tot de lessen bij de Koninklijke Militaire Akademie voorbereiden, om eenmaal naar Nederlandsch Indië te vertrekken (Breda: Broese, 1838), p. 293.

29 Franz Wilhem Junghuhn, Die Battaländer auf Sumatra, vol. 2 (Berlin: G. Reimer, 1847), pp. 1-28.

On the Balinese and the Batak, see p. 282.

30 Vickers, Bali, p. 86. 
Rizzoli's pelvimeter', he wrote, or they could have tested whether the differences in dimensions of the female pelvis were measureable. ${ }^{31}$

Third, discussions about the make-up of the entire archipelago focused on the difference between Malays in the western half of the archipelago and Papuan 'races' in the east. Alfred Russel Wallace, for example, who conceived of a dividing line between the fauna of the Asian west and the Australian east, also drew a line for the races of the region. By doing so he created a dichotomy between the almond-eyed, straight-haired people of the west and the darker, frizzy-haired people of the east. The Balinese and the Sasak of Lombok lived west of Wallace's line and Wallace considered these groups Malays. Other travellers however, observed 'Alfur' (a term used for the original inhabitants of the Moluccas and nearby areas) or Papuan features on Bali too. The Dutch Henri van Kol, for example, was of the opinion that the Sasak had smaller, more squat bodies with darker skin, the last trait usually seen as Papuan influence. ${ }^{32}$

Fourth, there was the question of Indian, or 'Aryan', influence. ${ }^{33}$ Because of the obvious Hindu influence on Bali, the idea developed that Indian racial features were also still visible on Bali, especially among the higher Hindu castes. In the 1930s Miguel Covarrubias, whose Island of Bali was a favourite amongst tourists, wrote that 'the Balinese have small but well-developed bodies, with a peculiar anatomical structure of simple, solid masses reminiscent of Egyptian and Mycenaean sculptures' ${ }^{34} \mathrm{He}$ compared these noble features with the more primitive ones he also observed: 'Some have large almond eyes, often with the "Mongoloï" fold, convex noses, and fine mouths; others have the concave, flat, broad noses, the squinty eyes, bulging foreheads, and prognathic jaws of the more primitive Indonesians'. ${ }^{35}$ The 1938 Balinese study by German physical anthropologist Ernst Rodenwaldt is an example of this tendency to look for Aryan influences. A few years before Kleiweg travelled to Bali, Rodenwaldt had broached the question of whether racial differences could be measured according to the different Hindu castes in Bali. He took measurements of individuals from different castes and though he found the foreheads of Brahmin men higher than those of other groups, he concluded that his measurements were unsatisfactory. However, he maintained the validity of his observations of physical difference between the lower and higher castes; his expert eye had been sharpened by long experience in the Indies. ${ }^{36}$ Besides this Indo-Aryan influence, an element of southern India, called Vedda, was also seen as part of the racial make-up of the archipelago and conceptualised with features such as dark skin and wavy hair.

31 Julius Jacobs, Eenigen tijd onder de Baliers: eene reisbeschrijving met aanteekeningen betreffende hygiëne, land- en volkenkunde van de eilanden Bali en Lombok (Batavia: Kolff, 1883), pp. 74-5. See also Vickers, Bali, p. 86. Vickers is not correct when he says that Jacobs' observations indicated 'racial similarities between Balinese, Javanese and other "Malays"'.

32 Alfred Russel Wallace, The Malay Archipelago: The land of the orang-utan and the bird of paradise: $a$ narrative of travel with studies of man and nature (London: Macmillan, 1886); Henri van Kol, Uit onze koloniën: uitvoerig reisverhaal (Leiden: Sijthoff, 1903).

33 See Tony Ballantyne, Orientalism and race: Aryanism in the British Empire (Basingstoke: Palgrave, 2002).

34 Miguel Covarrubias, Island of Bali (New York: Alfred A. Knopf, 1937), p. 12.

35 Ibid., pp. 16-17.

36 Ernst Rodenwaldt, 'Die nicht gemeinsamen Rasseelemente der Balischen Kasten', Archiv für Rassenund Gesellschaftsbiologie 32 (1938): 142. 
Finally, a distinction was made between the Hindu castes and those seen as the original inhabitants of Bali, the Bali-Aga. According to Henk Schulte Nordholt, scholarly attention in the 1930s shifted to the original, primeval Bali, as it was before Hinduism reached the island. This Bali could be found in the Bali-Aga villages, which were thought to have resisted Hindu influence. ${ }^{37}$ These villages were mostly located in the mountains on the eastern side of the island. The villagers considered themselves the original inhabitants of Bali, and colonial officials and ethnologists accepted this and incorporated it into their classifications. Covarrubias, and many others, considered the Bali-Aga as the pure descendants of these original inhabitants. This was why Margaret Mead and Gregory Bateson, after their stay in the south of Bali for several months, moved to the north, to Bayung Gede, a Bali-Aga village where they hoped to find the 'native' Bali. Mead wrote to Franz Boas in 1938: 'It has been customary to say that the mountain villages of Bali are almost completely different from the higher culture of the Plains, and yet in analysis the basic pattern turns out to be almost identical. ${ }^{38}$

In recent decades the notion of the people of the Bali-Aga villages as 'original' has been criticised by anthropologists and historians. It is misleading, according to Michael Hitchcock:

Mountain peoples are regarded as the original, asli, inhabitants of the Indonesian archipelago and are often seen as not fully incorporated into the world religions such as Hinduism, Buddhism and Islam that flourish in the low-lands and coastal areas of Indonesia ... [However,] even though they share many cultural characteristics with the non-Hindu peoples of the islands to the east of Bali, the Bali Aga were subjected to Hindu influences like their lowland neighbours. ${ }^{39}$

Brigitta Hauser-Schäublin also points to what she calls the 'more than 150-year-long discursive construction of "Bali-Aga", and Reuter shows how the northerners missed the opportunities of the tourist boom and were 'cast as a rather cultureless people by comparison to the glamorous courtly civilization of the south'. ${ }^{40}$ Schulte Nordholt has argued that this discursive tradition of the Bali-Aga was partly produced by a set of Dutch ethnologists. ${ }^{41}$ Victor Emanuel Korn's monograph on the village of Tenganan described the locals as less healthy than the inhabitants of the lowlands, emphasised the cultural difference between the Bali-Aga and the other Balinese, and explained cultural survival through isolation. Kleiweg must have decided to visit Tenganan because of Korn's work. ${ }^{42}$

37 Vickers, Bali; Schulte Nordholt, 'The making of traditional Bali', p. 112.

38 Margaret Mead, Letters from the field, 1925-1975, ed. Ruth Nanda Ashen (New York: Harper \& Row, 1977), pp. 213-14, quoted in Tessel Pollmann, 'Margaret Mead's Balinese: The fitting symbols of the American dream', Indonesia 49 (1990): 28.

39 Michael Hitchcock, 'Margaret Mead and tourism: Anthropological heritage in the aftermath of the Bali bombing', Anthropology Today 20, 3 (2004): 9-14.

40 Brigitta Hauser-Schäublin, "Bali Aga" and Islam: Ethnicity, ritual practice and "old-Balinese" as an anthropological construct', Indonesia 77 (2004): 27-55; Reuter, Custodians of the sacred mountains, p. 16.

41 Schulte-Nordholt, 'The making of traditional Bali'.

42 Victor Emanuel Korn, 'The village republic of Tenganan Pegeringsingan', in Bali: Studies in life, thought and ritual, ed. J.L. Swellengrebel (Dordrecht: Foris, 1984 [1933]), pp. 301-68; Christiaan J. Grader, who became a friend of the Kleiweg family, also wrote about village life in Bali: C.J. Grader, 


\section{Racialisations in field practice}

Kleiweg measured about a thousand people on Bali and another seven hundred on Lombok. He also took their fingerprints, and Frie Kleiweg de Zwaan-Vellema, who accompanied him, took about 1,500 photographs and assisted Kleiweg with the measurement of women. They believed that her presence and that of their daughter accounted for the many women they were able to measure. ${ }^{43}$

The daily practice of this fieldwork is better documented than other physical anthropological research from this period because both Frie Kleiweg de Zwaan-Vellema and her husband wrote about their research practice once they returned, in notes for lectures that they were going to give. These notes show how doing fieldwork propagated the idea locally that there was such a thing as race and that every individual could be defined racially. As Andrew Zimmerman has shown in a chapter on anthropological fieldwork in Germany, a survey of the German Anthropological Society 'taught the more than 6 million students whom it studied, as well as the teachers who collected the data, that Germanness could be perceived through "racial" characteristics that were publicly perceivable by any layperson'. ${ }^{44}$ By being part of anthropological fieldwork, anthropological subjects learnt about racial research from the explanations of anthropologists and their assistants, but they also experienced these notions physically, as they were measured.

The transfer of this knowledge depended to some degree on the extent to which the anthropologists were willing and able to explain their research to their local subjects. In places where there was less contact between colonisers and colonised, and where fewer outsiders knew local languages, there was probably less understanding of the purposes of anthropological research. Those who were not baffled by the process of being measured often expressed curiosity about their race. The Javanese, Chinese and Indian research subjects of the German anthropologist Bernhard Hagen, who worked in Sumatra, often wanted to know the purpose of the measurements. Hagen attributed this to their having higher intelligence than the less civilised races. ${ }^{45}$ Of course, local interpretations of racial research could be quite different from the purposes of those conducting the studies. Anthropologists noted, for example, that locals interpreted their work as a way to read the mind or as a way to test their fitness for coolie-work in the plantations of northern Sumatra. ${ }^{46}$

Because Bali had been under Dutch control since the early twentieth century, and because generations of ethnologists had preceded them, it was easy for the Kleiweg family to find their way around. In his published work, Kleiweg thanked both Dutch authorities and local rajas and village heads for their help. They were assisted by Dr Soedjono on Lombok and by the Anak Agung Anglurah Ketut of Karangasem on Bali, who became a friend of the family. ${ }^{47}$ Kleiweg was also aided by district officials Christiaan Grader and Roelof Goris, and he met the artist Walter Spies in Ubud,

'Tweedeling in het oud-Balische dorp', Mededeelingen Kirtya Liefrinck-Van der Tuuk 5 (1937): 45-71. On

Korn see also Reuter, Custodians of the sacred mountains, pp. 297-8.

43 Kleiweg de Zwaan family papers, Kleiweg de Zwaan's lecture notes, p. 22.

44 Zimmerman, Anthropology and antihumanism, p. 135.

45 Bernhard Hagen, Anthropologische Studien aus Insulinde (Amsterdam: Müller, 1890), p. 21.

46 See Sysling, Racial science and human diversity, p. 67.

47 Kleiweg de Zwaan family papers, Kleiweg de Zwaan, lecture notes, c.1940s, pp. 13, 17. 
who helped him with anthropological measurements and with the purchase of ethnographic objects.

Because Kleiweg wanted to conduct research with peoples that were as pure and original as possible, far from the Hindu plains of southern Bali, the family travelled to Karengasem, to Ubud, and to the Bali-Aga villages around Kintamani. They also visited Tenganan, a village known as Bali-Aga though it was hardly a mountain village and was only a short walk from the eastern coast. Kleiweg noted that in [the village of] Tenganan, people are strictly forbidden to marry outside the kampong. Those who do not abide to the rules are banned from the kampong. Because of this regulation anthropological research of this population was of course very interesting' because it was likely to have produced a pure 'racial type'. He thought, however, that the contrast between Hindu Balinese and Bali-Aga generally was too much viewed as an 'either ... or' ${ }^{48}$

The film footage which the Kleiwegs made in Bali shows, as well as the usual market and crafts footage, how they set up their anthropological laboratory. On what is probably the edge of a village, next to the rice fields, they set up a couple of tables and chairs. Kleiweg can be seen taking the measurements and calling out numbers, with his daughter sitting by the table and jotting down the numbers. The Balinese men are measured first and then photographed by Frie Kleiweg. ${ }^{49}$

As Mrs. Kleiweg's notes show, there was usually some reluctance that had to be overcome at the start of a measurement session. This was dealt with by first approaching the curious local youth with 'cans of colourful fruit drops [ulevellen]', but earlier publications written by Kleiweg were also circulated among locals to pave the way. ${ }^{50}$ These were possibly Kleiweg's books on Nias and Sumatra, and perhaps his De rassen van den Indischen Archipel [The races of the Indian archipelago]. Showing these books was another way in which locals encountered racial science. All Kleiweg's books included photographs; these were crucial in introducing people to racial research - and in engaging their interest. The men on Lombok, Frie Kleiweg wrote, were particularly interested in seeing photographs of Balinese women. Locals were told that their pictures, too, would be published, and were promised that they would receive a copy of their own photograph, and Frie Kleiweg wrote she was proud to have kept her word in every case. ${ }^{51}$ This means that Balinese and Lombok individuals carried home a photograph that was in most cases in an anthropological posture, in front or side view - images which supposedly showed their racial features. Mrs. Kleiweg also recounted how once, when she was working late at night on the veranda of the house, she was approached by a curious local man who had waited for a quiet moment to see the photographs she had taken. She was happy to show them. ${ }^{52}$

That the Balinese not only appreciated the photographs as souvenirs but were also aware of the sort of research the Kleiwegs were doing is clear from two anecdotes.

48 Kleiweg de Zwaan family papers, Kleiweg de Zwaan, 'Eene anthropologische studiereis in Bali en Lombok', lecture notes, c.1940s, p. 20; Kleiweg de Zwaan, Untersuchungen, p. 16.

49 The film footage is also in the Kleiweg de Zwaan family papers.

50 Kleiweg de Zwaan family papers, Mrs. Kleiweg de Zwaan-Vellema's notes, c.1940s, p. 5b.

51 Ibid., p. 8; paper sheet with catchwords for Mrs. Kleiweg de Zwaan-Vellema's lecture.

52 Mrs. Kleiweg de Zwaan-Vellema’s notes, c.1940, p. 10. 
The heads of the villages, Frie Kleiweg wrote, rarely had themselves measured, with a few exceptions. The head of one Bali-Aga village, for example,

asked my husband whether he had discovered differences in dimensions between the people in and outside of the Bali-Aga villages. When my husband answered positively, he took off his jacket [jasje] resolutely and had to be measured immediately, because he too was a Bali-Aga man and therefore an old race! His measurements are [now] hung in his veranda in a very fine golden frame. ${ }^{53}$

Because the category of Bali-Aga was of both local importance and of interest to the anthropologists - partly because of local claims of Indigenous origin - an individual Balinese could appropriate Western scientific notions to strengthen his identity claims.

A second man, a district head on Lombok, came to Kleiweg with a similar request, asking whether he had found differences between the Lombok and Bugi (Bugis) of South Sulawesi,

if so, he wanted to be measured. His father-in-law had often blamed him because he was not of similar birth to his daughter and said that their marriage was a misalliance. In fact the father-in-law had considered that his son-in-law must have had Bugi blood and Bugi were known as a people beneath them. [...] Anyway, this man received a colourful piece of paper in a golden frame and we hoped that he would have a greater say in things! ${ }^{54}$

This does not, however, mean that the people of Bali and Lombok were all interested in racial research. Part of the Kleiwegs' research was conducted in the prisons of Den Pasar, Karengasem and Singaradja, and in prisons on Lombok, because there were always people available and because it was possible to measure women there, 'something that was very difficult on Bali - and elsewhere, especially because we never forced these things' ${ }^{55}$ Christiaan Grader, the district officer on Bali who became a good friend of the Kleiwegs, wrote later that the Kleiwegs had asked permission of all the prison inmates to do the measuring, and each inmate was given some small compensation. This seems to have been an exception in physical anthropological research, especially in places like prisons where it was hardly possible to resist measurement. According to Grader, not one prisoner refused to be measured. ${ }^{56}$

There were also times when locals refused to do as Kleiweg wanted. He had decided to include taste research in his fieldwork. In the 1930s it had been found that some people found phenylthiocarbamide (PTC) very bitter while others taste nothing at all. This turned out to be a hereditary trait. ${ }^{57}$ Trying out taste research on the Balinese, Kleiweg was disappointed in the results and he suspected that many research subjects just repeated the answer of the person in front of them in the line. Also, as he had assumed the Balinese were more intelligent than the Sasak of Lombok, he was disappointed that more Sasak tasted the bitterness. He tried to

53 Ibid., p. 11.

54 Ibid., p. 11.

55 Ibid., p. 4.

56 Kleiweg family papers, 'Prof. Dr. J.P. Kleiweg de Zwaan', personal recollections by C.J. Grader, 18 Sept. 1985.

57 Kleiweg de Zwaan, Anthropologische untersuchungen, pp. 273-9. 
explain this away by pointing to the fact that on Lombok he had been assisted by his wife, who had more patience than the local Balinese doctor who had helped him on Bali. He did realise, however, that people from the Indies defined taste differently, and with different idioms, than Europeans. ${ }^{58}$ While locals appropriated some aspects of Kleiweg's research for their own purposes, they also helped to break down some of his preconceived ideas about race.

\section{Racialisations in Europe}

After returning to the Netherlands, Kleiweg set to work on a monograph based on his fieldwork, in German, still the academic language in the Netherlands. His book consists of a combination of descriptions and quantitative information, including charts and tables with the results of his measurements - a classic study of physical anthropology. A series of the fieldwork photographs are reproduced at the end.

In the book, Kleiweg racialised the Balinese and Lombok people by quantifying them, and abstracting them into lists of measurements. Measurements were seen as the most objective indications of racial difference. From the tens of thousands of measurements that he took, Kleiweg identified 27 bodily dimensions and indices, like shoulder width, in which the Bali-Aga and Balinese differed to a statistically significant degree. The Bali-Aga were slightly taller and their heads were slightly broader. Kleiweg was, however, cautious: these statistical differences did not necessarily mean that the Bali-Aga were another race. There were many dimensions and indices in which the Balinese and the Bali-Aga scored similarly, and other differences were not statistically significant, such as the cephalic index, the relation between the width and length of the head that indicated the difference between long-headed and short-headed people. At most, he wrote, the Bali-Aga could be said to contain some racial element that dominated a little more than in other Balinese.

Kleiweg also argued that differences between the Balinese and the Sasak were unimportant, while there were significant internal differences between the Bali-Aga villages. ${ }^{59}$ In the notes for a lecture he wrote that there were many different human types:

it is of the utmost difficulty for the anthropologist to make sense of this amalgam of types. Making the case even more complicated, one also has to ask whether the detected differences must indeed be understood as racial differences or merely as individual constitutional differences. ${ }^{60}$

Statistical difference was not the only key to racial difference for Kleiweg. The small differences between the Balinese and the Sasak were, he wrote, perhaps quantitatively but not qualitatively significant. ${ }^{61}$ Although measurement was the foundation of physical anthropology as a serious science, Kleiweg's indifferent results did not mean that he refrained from drawing conclusions at all. Indeed, he proceeded

58 Ibid., p. 279.

59 Kleiweg de Zwaan, Anthropologische Untersuchungen, pp. 287-9.

60 Kleiweg de Zwaan family papers, Kleiweg de Zwaan, 'Eene anthropologische studiereis in Bali en Lombok' (notes for a lecture), c.1940s, pp. 9-10. Research into constitutional types, following Ernst Kretschmer's typology, had become part of and had complicated anthropological studies.

61 Kleiweg, Anthropologische Untersuchungen, p. 304. 
to sketch an outline of the racial make-up of Bali and Lombok, but his personal observations now became as important as his measuring rods. Physical anthropologists considered themselves expert observers, trained as they were as medical students to study human bodies. They held that their medical background and fieldwork experience made their observations more valuable than those of amateurs. 'Only slowly', wrote German anthropologist Rodenwaldt, does the anthropologist 'acquire a sharpened eye for racial differences or for the elements of racial types in hybrids' ${ }^{62}$ By studying Indigenous people in their natural habitats, anthropologists trained their 'expert gaze' to internalise much that was impossible to measure. ${ }^{63}$

Kleiweg had had thirty years of experience with anthropological research, including two earlier research journeys to the Indies, and this experience made him capable of recognising racial traits that he had not been able to distinguish when he was younger. He now saw both the Balinese and the Sasak as a mix of the proto- and deutero- (secondary) Malay race. He also recognised Indo-Aryan, Mongoloid and Negroid elements, assessments based on typecasting rather than on measurement. Vedda racial features were linked to a deep dark skin and wavy hair, and Kleiweg thought he distinguished this in certain individuals. He also saw people who reminded him of Javanese, Minangkabau, Nias Islanders or Batak. Others seemed Indo-Aryan, Vedda, Melanesian-Negroid, Australian, Indian, Eskimo or Semitic. $\mathrm{He}$ also noted that some higher caste people had softer, whiter and more European looks. ${ }^{64}$

The photographs in the published book played an important part in his presentation and were meant to convey to the reader this qualitative information. Kleiweg thought that the photographs showed his impressions exactly - and that his own expertise in observation and visual judgement, coupled with the objectivity of the photographs, not only prevailed over his inconclusive quantitative results, but also allowed others to see the racial differences he had recognised. ${ }^{65}$ Reviewer Hendrik Bijlmer cautioned readers about the photographs in Kleiweg's book: 'Don't expect the usual images of the famous Balinese beauties', he wrote, 'on this fairy tale island, these do not even represent the average type!'66

\section{Conclusion}

Looking in detail at the making of anthropological knowledge on Bali and Lombok shows how the Balinese and Sasak were racialised through the work of anthropologists. In Kleiweg de Zwaan's work, written and published once he was back in Europe, this racialisation was complex. He was not convinced that the Bali-Aga differed racially from the other Balinese, or the Balinese from the Sasak, on the basis of his measurements. However, his book did feed back into preconceived

62 Rodenwaldt, 'Die nicht gemeinsamen Rasseelemente der Balischen Kasten', Archiv für Rassen und Gesellschaftsbiologie 32 (1938): 111-42.

63 See Michael Hau, 'The holistic gaze in German medicine, 1890-1930', Bulletin of the History of Medicine 74, 3 (2000): 515-20.

64 Kleiweg, Anthropologische Untersuchungen, pp. 26, 29.

65 Ibid., pp. 289, 304.

66 H.J.T. Bijlmer, 'J.P. Kleiweg de Zwaan, Anthropologische Untersuchungen auf Bali und Lombok' (Review), Nederlands Tijdschrift voor Geneeskunde 86 (1942): 1726. 
anthropological ideas about these groups, and Kleiweg emphasised his qualitative impressions, and trained intuitions, trying to communicate to his readers what the Balinese were like and how they related to other people.

In the course of anthropometric fieldwork, too, Indigenous subjects developed awareness of the idea that they differed physically from their neighbours. In the case of Bali and Lombok, some anthropological categories were appropriated by local communities. In the 1930s the Bali-Aga were seen as the original inhabitants of Bali by anthropologists, colonisers and tourists, but they also saw themselves as such, and still do. This is why a village elder had himself measured, to confirm the difference that he perceived between the Bali-Aga and the majority population of the island. Other anthropological debates, such as those around Aryan or Papuan influence, were - in this case - not treated as useful local indicators of difference. Similarly, on Lombok, the important local distinction was the Lombok-Buginese, rather than the Balinese-Sasak with which Kleiweg was preoccupied. Personal measurements, however, could also support local arguments. This means that racialisations occurred not only in the finished product of the monograph, but also at different moments of anthropological work, and with variable outcomes.

Tenganan is now a tourist village, as are a few other Bali-Aga villages. Reuter suggests that 'the Bali Aga villages presently known to scholars and tourists alike are those few that attracted the attention of colonial explorers in their initial search for pristine Balinese villages'. ${ }^{67}$ Racial difference is not the main marker of difference in today's discourses, which are chiefly framed in cultural and material terms. With the new possibilities of genetic research, however, the older categories of physical anthropology have begun to be reinvigorated. Recent research based on the $\mathrm{Y}$ chromosome of Balinese men suggests that much of their paternal gene pool derives from the Austronesian expansions from Taiwan, as the pre-Malay influence is now conceptualised. A smaller proportion (12 per cent) can be linked to migration from India. ${ }^{68}$ Because of the continuing interest of geneticists in 'older' and 'original' populations, the Bali-Aga may well receive renewed attention from these scientists.

67 Hitchcock, 'Margaret Mead and tourism', pp. 9-14.

68 T.M. Karafet, J.S. Lansing, A.J. Redd, S. Reznikova, J.C. Watkins, S.P. Surata, W.A. Arthawiguna, L. Mayer, M. Bamshad, L.B. Jorde and M.F. Hammer, 'Balinese Y-chromosome perspective on the peopling of Indonesia: Genetic contributions from pre-Neolithic hunter-gatherers, Austronesian farmers, and Indian traders', Human Biology 77, 1, (2005): 93-114. 